\title{
Correction to: Alexandra Cox: Trapped in a Vice: The Consequences of Confinement for Young People
}

New Brunswick, NJ: Rutgers University Press, 2017, 4181 pp, Series: Critical issues in crime and society, LCCN: 2017007405

\section{Marina Stokes ${ }^{1}$}

Published online: 21 June 2019

(c) Springer Science+Business Media, LLC, part of Springer Nature 2019

Correction to: Journal of Youth and Adolescence (2019)

48:1237-1239

https://doi.org/10.1007/s10964-019-01023-0

The original article was published with incorrect Author name in the title and throughout the book review article. The correct name in the title should read as "Alexandra Cox". 